\title{
Combining data on military supply and demand for arms production estimates
}

\section{Michael Brzoska}

Michael Brzoska is Senior Research Fellow, Institute for Peace Research and Security Policy, University of Hamburg, Hamburg, Germany, and Associate Senior Researcher, Stockholm International Peace Research Institute, Stockholm, Sweden. He may be reached at brzoska@ifsh.de.

\section{Abstract}

Currently there exist no data series comparing arms production values among countries. The article outlines three methods for generating such data series based largely on already available data series relevant to arms production, in particular series on arms imports and exports, procurement, and turnover figures from the world's largest arms producing companies. All three methods have major shortcomings and limitations but with additional effort in data collection they can provide a basis for comparing arms production values among countries as well as for regional and global totals. Furthermore, as the three methods use different definitions of the scope of arms production, comparison of the data produced by them can provide additional insights.

A number of data series exist on military-related issues, including (near-)global series on military spending, arms exports, and the world's largest arms producing companies, as well as more limited data series on procurement spending and military research and development. Global data series on national arms production currently do not exist. ${ }^{1}$

Data series on national arms production would be useful for several reasons. First, such data would be interesting in itself. Like data on other industries, time series could help to assess industry growth and contraction over time and data on several countries would allow for size comparisons. Second, when combined with other military-related data, such as figures on military expenditure and the arms trade, such data could broaden our understanding of military-industrial matters, for example the degree of countries' self-sufficiency in military matters. Third, set in relation to broad economic data such as GDP and overall industrial production, data on arms production could serve as an additional measure of the importance of military-related aspects of a country's economy. Fourth, a global estimate and a comparison of its national and regional components would be an additional indicator of military affairs both among states and globally. ${ }^{2}$

This article presents three methods for estimating countries' arms production values. They primarily use existing data from the data series mentioned above. This distinguishes them from estimates that, in addition to using available data on other aspects of military sectors, also use economic data, such as input-output tables (see below). The first method has already been used, for instance, to estimate arms production in Latin American countries (Lopes da Silva, 2018). The second method has been used in a number of earlier publications by various authors, while the third, which includes data on the world's largest arms producing companies collected by SIPRI, seems not to have been presented before. These methods can yield data for individual states and regions in addition to global estimates. To illustrate commonalities and differences among the three methods, this article produces data for a small selection of major arms producing countries. Estimation methods are explained below, and additional information on the methods is provided in Tables A1 to A3 (in the appendix). ${ }^{3}$

Each method can be used for the purposes listed above. The development of the methods adds the option of comparing data series that correspond to differing definitions and arms production valuations. It must be stressed, however, that all three methods are beset by major difficulties and shortcomings. The prime difficulty regards the glaring gaps in the data needed to calculate production values. This pertains both to the information as such and to the data's conformity to standardized definitions. Using available data series such as those described above presents something of a shortcut, as they are said to conform to standardized definitions. However, not least because of gaps in the available information necessary for checking conformity with standardized definitions, the data quality varies among countries.

As will become clear in the following discussion on the three methods, data on countries with fairly small arms industries tends to be particularly problematic. In addition, there also are highly contentious cases, such as Russia and China, among the major arms producers. Comparisons among countries with differing data sources are therefore problematic and need to be qualified. The comparative data presented below thus is intended as a first approximation in need of 
improvement through further work on the data. For regional and global estimates, data gaps for smaller arms producers may be less relevant than the problems associated with estimating production values in countries such as Russia and China.

The article proceeds as follows. It first discusses the current state of the data on domestic arms production and then presents the three aforementioned methods, including estimates for a limited selection of countries. The article then draws key conclusions, including from a comparison of the three series.

\section{Efforts to fill data gaps on arms production}

Data on the value of arms production is rare, nationally and even more so for sets of countries. There are a number of reasons for this. One is the difficulty of distinguishing arms production from civilian production as the two are becoming increasingly integrated. One solution to this problem is to estimate data corresponding to different definitions of arms production. Sometimes, direct and indirect arms production are distinguished, with direct production limited to goods specifically produced for military purposes and indirect arms production covering the production of dual-use goods sold to armed forces and all types of goods used as pre-products and components in military goods. ${ }^{4}$

Another reason lies in the way in which most countries construct industrial statistics. Traditionally, the materials they primarily work with, such as wood, chemicals, and metals, have defined most industries. Increasingly, however, major product lines have been added as defining industries, such as automobiles, machinery, airplanes, and information technology products. These generally also focus on some type of material, particularly metals, but not exclusively. While they overlap, in general these industries can still be clearly distinguished. In principle, the whole of arms production could be added to this list, although this would create substantial overlap with other industries, such as chemicals and metals mentioned above. International bodies in charge of defining industries have preferred in principle to stick with the larger industries rather than attempt to classify a broad arms industry. In the current 4-digit system of the International Standard Industrial Classification (ISIC, Rev. 4), various types of artillery, light weapons, small arms, ammunition, and the like are contained in category 2520. Military fighting vehicles also have a separate category (3040), as do Defense Activities (8422), which cover military operations. Warships, however, are not separated from civilian vessels (all in category 3011); nor are space and aircraft (3030), and all types of electric and electronic commodities (categories 2610 to 2790). The List of all Industrial Products, which forms the basis for the Industrial Commodity Statistics produced by the United Nations, is
The article first discusses the current state of the data on domestic arms production. It then presents three methods to estimate such data (with examples for selected countries). Finally, the article draws key conclusions, including from a comparison of the three series.

constructed in a similar way, distinguishing only a limited segment of arms production within categories that are separate from civilian production. ${ }^{5}$

Classifications can go deeper than 4 digits, and a limited number of countries have opted to add additional digits to their national classification systems, which separate civilian and military production (for instance in shipbuilding and space and aerospace). For some countries, it is therefore possible in theory to construct data for arms production from official sources beyond what the 4-digit ISIC classification provides. Gaps remain, however, particularly with respect to electric and electronic industries, where deep classification is especially difficult due to the similarities between many products used by the military and their civilian counterparts.

Finally, governments may be reluctant to publish data on national arms production, even where classification systems would allow for it. A few defense ministries have published estimates over the years, but definitions and the sources of the data basis have generally remained obscure. This raises an additional problem: Even if governments were to publish official data, it would not necessarily correspond to comprehensive definitions unless some international body were to provide them. The difficulties encountered in the past regarding the definition of military spending and arms transfers in the context of the reporting instruments of the United Nations indicate that this would be challenging with respect both to determining the proper boundaries of the defense sector and governments' political interests. ${ }^{6}$

Researchers interested in arms production data have therefore had to generate their own estimates. Employing a variety of methods - such as input-output analysis, collections of data on value-added by relevant companies, and the combination of procurement and trade data-these have only covered single countries, however, sometimes over several years, or groups of countries (such as the European Union) over a single year.

The closest researchers have come to a global estimate of arms production (or rather a near-global estimate, as data on China is missing) is SIPRI's annual data on the world's 100 largest arms producers, the Top-100 list. However, SIPRI collects data not on national arms production but on sales by major companies produced across national jurisdictions. As will be shown, this data series can still be used to supplement 
the estimation of data on national arms production. ${ }^{7}$

This brief discussion of the current situation with respect to arms production data indicates the variety of both estimation methods and data sources. Methods and data are closely interrelated, with specific methods requiring specific data. Unfortunately, this data is often only available as rough and/or gap-ridden estimates. Furthermore, all methods require that researchers make judgments, for instance on what counts as civilian and what counts as military production, as well as assumptions, for instance about the relative importance of industrial sectors in arms production.

As there is no generally accepted international definition of arms production, one can play with various potential conceptions, from major weapon systems to all goods used by the military. In what follows, I focus on three methods that use available data on both supply and demand with regard to military goods. The presentation of these methods does not imply that they produce more accurate data than other methods that involve integrated economic data, for instance data from (civilian) industrial sectors or input-output analysis. Indeed, as already mentioned and further detailed below, all estimation methods - mine and others - come with serious shortcomings and limitations. That said, each of the three methods considered here has the potential to provide rough estimates for comparisons among countries and for regional and global aggregates. Their advantage is that they are less dependent on national idiosyncrasies with respect to the primary data than methods using national data. Furthermore, the methods are simple and the necessary data is comparatively easily available, making it more likely that data on many (or even all) countries can and will become available in the future.

\section{Method 1: Major conventional weapons}

The first method addresses a very narrow conception of arms production. While it clearly does not cover all arms production, it does correspond to a widespread perception of what makes the industry special. In this regard, it is similar to the SIPRI data on trade in major weapons, which is widely accepted as an indicator of the arms trade in general. The basic conception of this method has recently been presented by Lopes da Silva (2018).

The core idea is to calculate a given government's procurement of major conventional weapons based on domestic production (which may, however, include imported intermediate products, discussed later on) and to add to this the value of its exports. Data on the quantity of major conventional weapons exports is readily available from SIPRI's Arms Transfer Database. ${ }^{8}$ Data on the procurement of major conventional weapons is in principle available from the same type of sources as used for the SIPRI arms trade data. Key sources for data on the procurement of major conventional weapons include national ministries of defense, handbooks, relevant company publications, specialized magazines, and the annual Military Balance publication from the International Institute for Strategic Studies (the primary source for the illustrative example in Appendix Table A1), which contains data on new procurement of weapon systems. Since annual domestic weapon procurement of weapon systems is the basis for estimation, data on domestic procurement can in principle be made consistent with the SIPRI arms trade data. However, while the same sources used for the data on arms trade can also be used for procurement data, the effort to create this data series would probably be demanding as procurement concerns more, and often not very common, items. SIPRI uses a pricing system that is designed to present the use-value of major weapon systems. This pricing system is used to provide what SIPRI calls Trend Indicator Values (TIV) for arms exports in its database on major weapon exports and can also be used to value domestic procurement. ${ }^{9}$

TIVs focus on a particular aspect of weapon systems, namely their competitive production costs. In principle, TIVs are based on the known unit production costs of a core set of weapons. ${ }^{10} \mathrm{~A}$ further assumption is that weapon systems with similar characteristics have similar prices. Prices for weapon systems for which data is not available are calculated based on these assumptions by comparing a limited number of physical characteristics. ${ }^{11}$ These estimates may differ from actual production costs. They are therefore not directly comparable to economic data such as data on industrial statistics or national income. Furthermore, arms producers may be more or less efficient than producers whose production costs are known, which implies that using TIVs may lead to the over- or underestimation of actual production values. As is the case for the SIPRI arms transfer data, comparisons of arms production among countries based on TIVs therefore focus on the military capabilities of industries rather than actual production values. ${ }^{12}$

Table 1 provides a summary of the example of this method a(nd is presented more fully in Appendix Table A1). As its purpose is to demonstrate the method, there is no claim to completeness with respect to domestically procured major weapon systems. A global estimate would need to be aggregated from national data. This would be a major effort at the gathering of data currently only available in scattered sources, and it is likely, as is the case with the SIPRI data on major weapons transfers ${ }^{13}$ that some gaps and puzzles would remain and would need to be filled and resolved by expert judgment.

There are several additional problematic issues with this 
method. One is the conception of arms production on which it relies. It obviously only covers a part of arms production. While major conventional weapons such as aircraft, warships, and battle tanks are very costly items that usually make up the bulk of procurement spending, there are important gaps in arms production that are not covered by SIPRI's definition of major conventional weapons. ${ }^{14}$ The most important of these concern small and light weapons, ${ }^{15}$ as well as military support equipment (such as unarmed special vehicles) not included in the SIRRI data. A second issue stems from the use of data on the delivery of weapons to customers of major weapon systems rather than data for production itself. Delivery schedules often do not coincide with production schedules, particularly when new weapon systems are introduced. A third issue concerns imports of components and pre-products, which are then integrated into other countries' arms production. This issue is largely ignored when only the final delivery of systems to customers is considered, but it can be important, particularly for countries with small production bases for such components compared to their major weapons production capabilities. Some major components, such as engines and radars, are separated out in SIPRI's arms trade data and could in principle also be separated out for procurement data; however, these are only some of the components and pre-products that, if imported, are not elements of a country's arms production.

These various limitations add up to the proposition that data calculated via this method is likely to be more reliable for countries and country groupings with large arms industries, primarily those that produce major weapons and their components. But for smaller arms-producing countries, where the production of small arms and light weapons and the importation of components and pre-products generally make up a higher share of total arms production than in countries with large arms industries, method 1 is likely to lead to a significant underestimation of arms production. Comparisons among countries with different arms production structures may therefore be misleading. The same goes for comparisons of arms production over time, which are likely to be more reliable for countries with large volumes of arms production than for countries where few items are produced and/or where deviations between production and delivery schedules may have a greater influence on trend data. These limitations, however, are less relevant to global estimates of arms production, which will be dominated by major producer countries.

Method 2: National procurement and arms trade data The second method starts off with a broader definition of arms production, corresponding to what is often classified as
Table 1: Method 1 estimates of major weapons production, selected countries, 2015

\begin{tabular}{|c|c|c|}
\hline & Category & $\begin{array}{l}\text { Total mn } \\
\text { TIV }\end{array}$ \\
\hline France & $\begin{array}{l}\text { Domestic procurement } \\
\text { (from national sources only) } \\
+ \text { Exports } \\
=\text { Total }\end{array}$ & $\begin{array}{r}837 \\
\frac{2,017}{2,854}\end{array}$ \\
\hline Russia & $\begin{array}{l}\text { Domestic procurement } \\
\text { (from national sources only) } \\
\frac{+ \text { Exports }}{=\text { Total }}\end{array}$ & $\begin{array}{r}7,504 \\
\frac{5,842}{13,346}\end{array}$ \\
\hline USA & $\begin{array}{l}\text { Domestic procurement } \\
\text { (from national sources only) } \\
\frac{+ \text { Exports }}{=\text { Total }}\end{array}$ & $\begin{array}{r}21,648 \\
3 \frac{9,931}{31,579}\end{array}$ \\
\hline
\end{tabular}

equipment investment in procurement or viewed as the industrial source for military exports, for instance in the European Union's Common Military List. ${ }^{16}$ No further effort to construct a consistent definition is made here, although such a definition would be required to arrive at more valid estimates than those presented here. Arms production in a particular country $P_{i}$ is calculated by adding national procurement $\left(D_{i}\right)$ and exports $\left(X_{i}\right)$ but subtracting imports $\left(M_{i}\right),{ }^{17}$ so that

$$
P_{i}=D_{i}+X_{i}-M_{i}
$$

Appendix Table A2 illustrates the method and uses data that allows for the constructing of corresponding data series on arms production. Since data for arms exports, arms imports, and procurement needs to conform to standard definitions, data sources that claim to have standardized the data are preferable. Examples of such sources for regions include the European Union's arms transfers data and NATO procurement data. ${ }^{18}$ NATO provides a short list of items the procurement of which should be included in this subcategory of defense expenditures and which one would hope to see included in a comprehensive definition of arms production. It is likely that some non-NATO member countries will publish data on procurement which is similar to the NATO data, but many will not.

In the World Military Expenditures and Arms Transfer series, the U.S. government publishes data on arms imports and exports, for which a comprehensive definition is provided. ${ }^{19}$ However, it is questionable whether data on exports and imports actually corresponds to a common standard. ${ }^{20}$ National data on procurement, arms exports, and imports, while often 
corresponding to idiosyncratic definitions, can help to fill gaps and to determine the plausibility of data in broader series. For some countries, no relevant data is available, and the figures must be estimated. One possible way to do this is via parametric estimation of different factors, such as GDP and military spending per soldier, which likely shape procurement spending in countries where data is available. But the profiles of these countries (e.g., NATO member states) may be quite different from countries where estimates are needed. ${ }^{21}$

Table 2 is an illustration of the data produced for Appendix Table A2 which, itself, is provisional and does not represent the best data that would be available with more time and effort. For Appendix Table A2, NATO data on "equipment expenditures" was used for NATO member countries. Estimation will be necessary to fill the gaps. The data for China and Russia in Table A2 was estimated using a very simple method: It was assumed that the share of procurement in military expenditures was the same as that of the United States. More complex estimation procedures would have to be used for more accurate estimates of missing data. Data for arms imports and exports is taken from WMEAT data series, ${ }^{22}$ except for the U.K., where the U.S. government data for 2015 was far beyond what is plausible given earlier data for the U.K. and data on exports of major weapons from that country as reported by SIPRI.

While attractive in principle due to its wider scope (which corresponds to a broader, more widespread definition of arms production), method 2 nonetheless faces serious issues related to definitions and data requirements. Furthermore, as with method 1 , there is the issue of estimating production based on the weapons' final consumption - composed of total national procurement plus exports. That is, the method assumes that all imports are imports by the final consumer, the national government, when imports may in fact include pre-products and components for the importing countries' arms industries and thus should not count as final consumption but as intermediate products. Put differently, there is an element of double-counting at least some imports. Still, because of the broader scope of products included in this method, these problematic issues may be of lesser importance if they are dealt with properly, particularly if moving averages rather than annual data are used.

The various limitations mentioned above, as well as the shortcuts made for the sake of presenting the principle of the method, allow for only rough country estimates in Tables 2 and A2. Much more work would be needed to arrive at more concise and comparable estimates. In some respects, a global estimate would be easier to produce than a set of many national estimates. Procurement data for all countries would suffice, as imports and exports would cancel each other out. Nevertheless, export data would be helpful in constructing procurement data, particularly for countries in which domestic arms industries are either very small or nonexistent.

Method 3: Combining procurement, export, and sales data As discussed, methods 1 and 2 are afflicted with deficient reporting on imported components and pre-products - method 1 because this aspect of arms production is wholly ignored, and method 2 because all imports are taken as final consumption by national governments. Method 3 reveals, in a preliminary way, how using the SIPRI data on arms producers (rather than production) might help to address the second issue. Method 3 thus is an extension of method 2, at least for countries that have a good number of companies in SIPRI's Top-100 list.

The SIPRI Arms Industry Database reports sales (sometimes called turnover). In many countries, sales data (by industry) is aggregated as gross output in national account statistics. As pre-products, services, and so on bought from other companies are also included in sales, adding up sales results in double-counting items which are traded among 
companies. For this reason (there are some additional, less important issues, e.g., regarding taxes, which I will not deal with here), many economists prefer net production values, known as gross domestic or, with some differences, national product or national income (respectively, GDP, GNP, GNI). ${ }^{23}$ Similarly, I would assume that most observers would find national, and global, data on arms production (without doublecounting) preferable to sales data. As only the arms sales data in the form of the SIPRI Top-100 data is available, however, it is often perceived, in my view justifiably, as a valid indicator of arms production by the largest companies. ${ }^{24}$ But it is more problematic to use this data as an indicator of the relative weight of countries. One reason is that sales by companies may stem from production in a different country than that in which the company is registered and thus located in the SIPRI Arms Industry Database. ${ }^{25}$

In full awareness of the major problems associated with the SIPRI Top-100 data-the potential double-counting, the exclusion of all smaller companies, and production in countries other than that in which the company is registered-method 3 makes use of this data. More concretely, method 3 uses the crucial, and certainly controversial, assumption that sales by companies from the Top-100 in a country $\left(S 100_{i}\right)$ are a rough estimate of domestic arms production $\left(P_{i}\right)$ in that country. Put differently, arms sold by smaller companies to governments as final customers are treated as if they were pre-products and components bought by the Top-100 companies from domestic sources. Clearly, if it is valid at all, this is likely to be more valid in some countries than in others. In particular, there is a bias against countries with no or few companies which make it into the Top-100 list, even though domestic arms production is substantial. Method 3 is therefore systematically skewed toward countries with large arms producing companies, severely limiting the validity of comparisons among countries. For some countries, having data on many smaller companies might help to at least partially address this problem.

As mentioned several times before, the purpose here is to outline a method rather than to provide adequate estimates. The method is based on the idea that not all relevant components and pre-products will come from domestic sources and that some will instead be imported $\left(M P_{i}\right)$ as a part of the total arms imports $\left(M_{i}\right)$. Method 3 thus differs from method 2, where arms imports are not divided between those that are government procurement purchases $\left(M G_{i}\right)$ and those that are used as components and pre-products by arms producing companies $\left(M P_{i}\right)$.

Formally, the two preceding paragraphs can be written as

$$
S 100_{i}=P_{i}+M P_{i}
$$

Table 3: Percentage comparison of estimates of arms production with methods 2 and 3 , selected countries, 2010-2015

$\begin{array}{lcccccc} & ‘ 10 & 11 & ' 12 & ' 13 & ' 14 & 15 \\ \text { France } & 22 & 24 & 24 & 35 & 29 & 27 \\ \text { Germany } & 20 & 11 & 7 & 14 & 29 & 1 \\ \text { Russia } & -84 & -99 & -75 & -40 & -24 & -21 \\ \text { UK } & 43 & 30 & 59 & 42 & 47 & 24 \\ \text { USA } & 23 & 5 & 7 & 14 & -5 & -12\end{array}$

Note: Positive values show the extent to which sales by Top100 arms producers are greater than estimates based on method 2; negative values occur where sales by the Top-100 arms producers are lower than method 2 estimates. Sources: Appendices 2 and 3.

(3) $M_{i}=M P_{i}+M G_{i}$.

Combining (2) and (3) then gives

$$
S 100_{i}=P_{i}+\left(M_{i}-M G_{i}\right)
$$

and, hence,

$$
-M G_{i}=S 100_{i}-P_{i}-M_{i}
$$

Equation (1)-that is, $P_{i}=D_{i}+X_{i}-M_{i}$ from method 2 - can now be restated to accommodate the fact that only imports by governments constitute proper final consumption, whereas other imports are pre-products and components, which do not count as government final consumption. Thus,

$$
P_{i}=D_{i}+X_{i}-M G_{i}
$$

Combining (5) and (6) then yields

$$
\begin{aligned}
& P_{i}=D_{i}+X_{i}+\left(S 100_{i}-P_{i}-M_{i}\right), \\
& 2 P_{i}=D_{i}+X_{i}+\left(S 100_{i}-M_{i}\right), \text { and } \\
& P_{i}=\left[\left(S 100_{i}\right)+\left(D_{i}+X_{i}-M_{i}\right)\right] / 2,
\end{aligned}
$$

so that method 3 works out as averaging data from method 2 and data on the Top-100 arms producers. Note, however, that this correction for aspects of the component imports issue cannot work for countries that do not have companies in the 
Top-100 list. Furthermore, in no case will the companies in the SIPRI Top-100 list represent all of the arms production being carried out. The share covered by companies from the list is also likely to differ from country to country, which means that the extent of the correction for component imports will differ, limiting the validity of comparisons among countries.

Method 3 has major limitations and shortcomings that reduce its value in correcting for the shortcomings of method 2 . Still, appendix Table A3 presents preliminary estimates using this method. The data produced with method 3 differs substantially, at least for most countries, from that resulting from method 2 . The data showing the percentage differences between the two estimate methods is presented in Table 3. The difference is small for the United States and, for Russia, has been steadily decreasing over time, having been quite large in earlier years. It is also large for most other countries, including the U.K. This is largely due to the lack of data on smaller companies in the SIPRI dataset, which leads to an upward bias in estimates that use method 3 for countries that host a disproportionate number of large arms producing companies and an underestimation of national production for countries where there are comparatively few large arms producing companies. While the lack of data on all arms producers introduces a bias in estimates based on method 3, the inclusion of data beyond sales to procurement authorities adds additional information which must be interpreted in light of this bias.

\section{Conclusion}

The three methods suggested in this article are based on different primary data sources, each of which comes with its own drawbacks. Combining data and comparing the results of the three methods can shed light on national arms production, where data has been particularly scarce for most countries. Nevertheless, all three methods have major limitations and

$$
\begin{array}{lll}
\text { Method } 1 & \text { Method 2 } & \text { Method } 3
\end{array}
$$

Very narrow but fairly Broader but vague. clearly defined.

Exports; procurement from domestic sources.

SIPRI major weapons exports data; IISS Military Balance.

\section{Data on procurement of weapon systems by year from multiple sources.}

Data is not of
production per se but
consumption; inclusion
of imports of most
components and pre-
products; estimates
necessary for many
countries.

\author{
National procurement; \\ arms imports; arms \\ exports. \\ National and NATO \\ data on procurement; \\ national data on arms \\ exports; U.S. \\ government data.

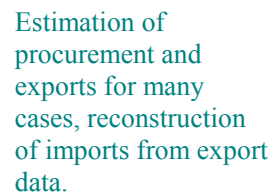 \\ Still consumption \\ rather than production, \\ although less \\ problematic than for \\ method 1; data from \\ sources with differing \\ definitions; estimates \\ necessary for many \\ countries. \\ Similar to method 2 \\ but with corrections \\ for imports of \\ components and pre- \\ products by \\ companies. \\ As for method 2, plus \\ sales by SIPRI Top- \\ 100 companies. \\ As for method 2, plus \\ SIPRI Top-100 \\ companies data. \\ As for method 2, plus \\ data on smaller arms \\ producing companies. \\ As for method 2, plus \\ differences between \\ countries with respect \\ to the share of national \\ arms production \\ represented by major \\ arms producing \\ companies from a \\ particular country.
}

shortcomings resulting from data gaps, differences between reported data and presumed definitions, and assumptions that must be made about the importation of pre-products and components used in national arms production. The methods adopt different approaches for overcoming these and other limitations and shortcomings, in part by introducing new ones. Without very substantial work on filling data gaps and making available data more commensurate with standard definitions, comparisons among countries and regional or global estimates will remain problematic. That said, rough estimates are possible with more limited extensions to available datasets.

Table 4 presents a summary of the three methods, highlighting in particular the differences between method 1, on the one hand, and methods 2 and 3 on the other. Method 1 corresponds to a very narrow conception of the arms industry, while the other two cover a wide range of production activities linked to demand for military products.

A rough comparison of three countries for which estimates were made using simple variants of the three methods reveals 
substantial differences, particularly between method 1 as against methods 2 and 3 (see Table 5). The main reason is that the data for method 1 is constructed by using SIPRI's trend indicator values (TIVs), which in turn use estimates of prices for major weapon systems corresponding to their military usevalue, whereas the other two methods are based on market exchange rates. To the extent that TIVs reflect actual military use-values, the prices used in the SIPRI system express a variant of purchasing power parities for major weapon systems. ${ }^{26}$ Limited by the data that goes into their calculation, SIPRI's price estimates represent the international competitiveness of particular weapon systems based on physical characteristics.

The differences among the estimates are particularly striking for the case of Russia. Measured in terms of purchasing power parities, the output of its arms industry is substantially larger than the figure obtained when using market exchange rates. It is worth stressing again, however, that data issues, in particular the roughness of the estimate of Russian procurement and the different sizes of the various companies in the countries, may bias the comparison.

Despite the shortcomings and limitations of all three methods, the data presented in Table 5 does point toward an interesting result which requires further analysis (with the help of better data). Other comparisons may lead to other interesting conclusions.

None of the methods presented here provide an alternative to better and more standardized data on arms production. However, they may help to generate estimates that are in the right ballpark for comparisons among countries and for regional and global aggregates. To achieve this goal, all methods require additional work with regard to data, but that is likely to be more limited in scope than to get reliable standardized estimates for arms production by other methods.

Estimates that use method 1 are likely to produce valid results with substantial but reasonable effort based on proven methods for collecting data on procurement. The other two methods have more intricate data demands, particularly with respect to standardization. However, with some corrections to the available and rough estimates of missing data, they may serve to reduce the shortcomings of method 1, particularly its limited definition of arms production. ${ }^{27}$

The purpose of this article is to demonstrate that progress in producing estimates of arms production values can be achieved by methods that are largely based on existing data series on particular aspects of the military sector. My hope is to stimulate further work that extends to comparing the methods suggested here with other, previously proposed, methods. On the one hand, this work must be conceptual; it
Table 5: Relative size of arms production, selected countries, $2015(\mathrm{USA}=100)$

$\begin{array}{lccc} & \text { Method 1 } & \text { Method 2 } & \text { Method 3 } \\ \text { France } & 9.1 & 7.5 & 11.4 \\ \text { Russia } & 42.3 & 12.5 & 11.7 \\ \text { USA } & 100 & 100 & 100 \\ & & \end{array}$

must assess whether there are better ways to deal with some of the shortcomings and limitations of the methods presented in this article. On the other hand, and primarily, it must also involve an empirical component, in particular the production of more standardized data on procurement.

\section{Notes}

1. Military spending: SIPRI, Military Expenditure Database, https://www.sipri.org/databases/milex; United States Department of State, various years; IISS, various years. World Bank, World Bank Open Data, https://data.worldbank.org/. Arms exports: SIPRI, Arms Transfer Database, https://www.sipri.org/databases/armstransfers; United States Department of State, various years; Theohary (2017). Arms producing companies: SIPRI, Arms Industry Database, https://www.sipri.org/databases/armsindustry. Procurement spending: For NATO member states: NATO, various years. Military $R \& D$ : For OECD member states: OECD, Research and Development Statistics, https://stats.oecd.org/Index.aspx? DataSetCode=GBAORD_NABS2007.

2. For several reasons: See also Fleurant and Tian (2018); Dunne (2009); Hartley (2018); Hartley and Belin (2020). Industrial production: Beyond what is proposed by Wulf (2018), using data from the SIPRI Arms Industry Database. $A$ country's economy: Care would have to be given to ascertain the compatibility of the results of such estimations with economic data.

3. Three methods: Unless stated differently, "arms" and "arms production" are used throughout this text interchangeably with "military equipment" and "defense production".

4. Data is rare: Exceptions include Brzoska and Ohlson (1986) and Neuman (2006); see also Wulf (2018) and Hartley and Beilin (2020). Increasingly integrated: See, e.g., Wulf (2003); Dunne (2009); Hartley (2018).

5. International Standard Industrial Classification: United Nations (2008). Industrial Commodity Statistics: https://unstats.un.org/unsd/industry/Commodity/TechNotes.c shtml.

6. Difficulties encountered: See, e.g., Brzoska (1995); Chalmers, Donowaki, and Greene (1997). 


\section{Sales by major companies: Fleurant and Nan (2018).}

8. https://www.sipri.org/databases/armstransfers.

9. SIPRI kindly provided TIV data for the weapon systems used for the calculation in Table A1 for which TIVs exist in the SIPRI database.

10. See https://www.sipri.org/databases/armstransfers/sourcesand-methods\#Coverage.

11. The same method could in principle be used for weapon systems that are only procured domestically and for which there is no TIV in the SIPRI system. However, estimation of prices on the basis of the physical characteristics of weapon systems may be preferable to using actual production costs, even where available. In economic terms, there is a fundamental difference between the two methods used by SIPRI for obtaining TIVs described above. While actual cost may or may not be competitive, using physical characteristics for estimation assumes that they are. The difference is likely to be less important for weapons that are internationally traded (and thus generally need be competitive) than for weapon systems that are only procured domestically (and may therefore be highly subsidized). When combining procurement and trade data, as suggested here, it makes sense to use TIVs that assume the competitiveness of prices of weapon systems based on their values. Further information of the details of SIPRI's TIV estimation, would, however, be necessary for any outside researcher who wanted to make such estimates independently of SIPRI.

12. Robertson and Adrian (2017) have developed, for the example of China, a relative military cost/price index based on the relative unit costs of inputs into arms production. This is in the spirit of using data on (civilian) industries (see, Wulf, 2018, and Yesilyurt, et al. 2014) but would require much additional work to arrive at estimates for many countries.

13. See SIPRI's method section regarding its major weapons transfer data, https://www.sipri.org/databases/armstransfers.

14. SIPRI Arms Transfer data covers all fixed-wing aircraft and helicopters, including unmanned aircraft (UAV/UCAV) with a minimum loaded weight of $20 \mathrm{~kg}$, air defense systems, naval ships, anti-submarine warfare weapons, all vehicles with integral armor protection, including all types of tanks, guided missiles, bombs and shells, reconnaissance satellites, and artillery with a caliber equal to or above $100 \mathrm{~mm}$, as well as engines, major sensors, and selected components for the listed weapon systems. For details, see Sources and Method, https://www.sipri.org/databases/armstransfers/sources-and-m ethods\#Coverage.

15. The prime reason for SIPRI's limitations in the coverage of arms transfers is the scarcity of data beyond major conventional weapons. That said, there have been several attempts to estimate production and trade in small arms, particularly by the Geneva-based Small Arms Survey (http://www.smallarmssurvey.org/) and the now-defunct Norwegian Initiative on Small Arms Transfers (http://nisat.prio.org/). This data could provide a basis for rough estimates on small arms and light weapon production to supplement the data produced with the methodology outlined here.

16. See https://eur-lex.europa.eu/legal-content/EN/TXT/?uri= CELEX\%3A52015XG0421\%2805\%29.

17. As discussed later on, not all imports are carried out by governments. At this point, because of a lack of data to distinguish imports by governments from imports by companies (which become pre-products and components), this issue will be ignored.

18. European Union data: Available since 1999 and published in pdf format by the European External Action Service https://eeas.europa.eu/headquarters/headquarters-homepage/ 8472/annual-reports-on-arms-exports-_en. NATO data: See https://www.nato.int/nato static fl2014/assets/pdf/pdf 2017 _06/20170629_170629-pr2017-111-en.pdf. Listed are: $\overline{(2.1 .1)}$ missile systems; (2.1.2) missiles (conventional weapons); (2.1.3) nuclear weapons; (2.1.4) aircraft; (2.1.5) artillery; (2.1.6) combat vehicles; (2.1.7) engineering equipment; (2.1.8) weapons and small arms; (2.1.9) transport vehicles; (2.1.10) ships and harbor craft; and (2.1.11) electronic and communications equipment. NATO's “equipment expenditures" list does not include the procurement of components and pre-products for spare parts or for ammunition. On the other hand, procurement for nuclear forces is included. One of the academic studies that have used this data is Bove and Cavatorta (2011).

19. United States Department of State (2017). Prior editions are available at various places on the internet and, for earlier years, in printed form. See also Theohary (2017) for another report that uses U.S. government data on arms exports in a differing format.

20. WMEAT arms import and export data is a mixture of actual financial flows and estimates of the value of arms transferred. WMEAT therefore cautions against comparing the value of arms imports to values for other parameters, such as GDP or military expenditure. Inconsistencies in the WMEAT data relate to inconsistent services, dual-use goods, as well as data on licence applications versus actual deliveries; see United States Department of State (2017), Sources, Data and Methods section. A particularly puzzling case is that of U.S. arms exports, which are extremely high in the WMEAT data, corresponding to over 80 percent of the global total for the period 2011-2015 (United States Department of State, 2017, Table II). The high U.S. numbers are explained in WMEAT as deriving from the inclusion of commercial sales in the data. In many countries, however, arms sales are predominantly by commercial sellers.

21. In principle, a synthetic control approach would be preferable by constructing a "synthetic" country for which data is needed from the range of countries of which reliable data is available. At least for the time being, however, the data on procurement is so limited that such an estimation does not seem possible. 
22. United States Department of State, various years; see also Theohary (2017).

23. National income can, for instance, be arrived at by aggregating the value-added of the relevant companies, thus eliminating double-counting. Some economists, however, argue that much can be learned about the state of the economy by analyzing gross output; see, e.g., Skousen (2015). For 2016, the U.S. Bureau of Economic Analysis estimated U.S. gross output of USD32.4 trillion, compared to GDP of USD18.7 trillion.

24. In addition to the three methods suggested here, it would of course be possible in principle to arrive at estimates of national and global arms production by expanding the scope of companies to include smaller companies and by using company data on net production (or value-added) instead of sales data. This would, however, require collecting much additional data, some of which, such as value-added in arms production, does not seem to be widely available.

25. This is partly corrected for in the SIPRI data by listing major subsidiaries separately.

26. In addition to Robertson and Sin (2017), see also United States Department of State (2017), the Sources and Methods section of which contains a discussion on PPPs in the military sector.

27. Global estimates for methods 2 and 3 could be reduced to the aggregation of national procurement, such as imports and exports of arms, and certain components would cancel each other out.

\section{References}

Bove, V., and E. Cavatorta. 2011. "From Conscription to Volunteers: Budget Shares in NATO Defence Spending." Defence and Peace Economics. Vol. 23, No. 3, pp. 273 288. http://dx.doi.org/10.1080/10242694.2011.563973

Brzoska, M. 1995. "World Military Expenditures," pp. 45-67 in K. Hartley and T. Sandler, eds. Handbook of Defense Economics. Volume 1. Amsterdam: North Holland. https://doi.org/10.1016/S1574-0013(05)80005-5

Brzoska, M., and T. Ohlson, eds. 1986. Arms Production in the Third World. Oxford, UK: Oxford University Press.

Chalmers, M., M. Donowaki, and O. Greene. 1997. "Developing Arms Transparency: The Future of the UN Register.” Bradford Arms Register Studies No. 7. Bradford, UK: University of Bradford.

Dunne, J.P. 2009. "Developments in the Global Arms Industry from the End of the Cold War to the Mid-2000's," pp. 13-37 in R.A. Bitzinger, ed. The Modern Defense Industry: Political, Economic, and Technological Issues. Santa Barbara, CA: Praeger.

Fleurant, A., and N. Tian. 2018. "SIPRI's Arms Producing and Military Services Companies Database." The Economics of Peace and Security Journal. Vol. 13, No. 2, pp. 5-10. https://doi.org/10.15355/epsj.13.2.5
Hartley, K. 2018. "Arms Industry Data: Knowns and Unknowns." The Economics of Peace and Security Journal. Vol. 13, No. 2, pp. 30-37. https://doi.org/10.15355/epsj.13.2.30

Hartley, K., and J. Belin, eds. 2020. The Economics of the Global Defence Industry. London: Taylor and Francis.

[IISS] International Institute for Strategic Studies. 2016. Military Balance 2016. London: Routledge.

Lopes da Silva, D. 2018. "Filling Arms Production Data Gaps: South America as a Case in Point." The Economics of Peace and Security Journal. Vol. 13, No. 2, pp. 19-25. https://doi.org/10.15355/epsj.13.2.19

[NATO] North Atlantic Treaty Organisation. 2017. "Defence Expenditure of NATO Countries (2010-2017)." Press Release 29 June 2017 COMMUNIQUE PR/CP(2017)111, https:/www.nato.int/nato_static_fl2014/ assets/pdf/pdf_2017_06/20170629_170629-pr2017-111 -en.pdf .

Neuman, S.G. 2006. "Defense Industries and Global Dependency." Orbis. Vol. 50, No. 3, pp. 429-451. https://doi.org/10.1016/j.orbis.2006.04.004

Robertson, P.E., and A. Sin. 2017. "Measuring Hard Power: China's Economic Growth and Military Capacity." Defence and Peace Economics. Vol. 28, No. 1, pp. 91-111. https://doi.org/10.1080/10242694.2015.1033895

Skousen, M. 2015. "On the Go: De-Mystifying Gross Output.' Eastern Economic Journal. Vol. 41, No. 2, pp. 284-288. https://doi.org/10.1057/eej.2014.65

Theohary, C.A. 2016. "Conventional Arms Transfers to the Developing World." Washington, D.C.: Congressional Research Service. Available at https://fas.org/sgp/crs/ weapons/R44716.pdf.

United Nations. 2008. "International Standard Industrial Classification of All Economic Activities." New York: United Nations. https://read.un-ilibrary.org/economic-and -social-development/international-standard-industrial-cla ssification-of-all-economic-activities-isic-rev-4_8722852 c-en\#page5.

United States Department of State. 2017. World Military Expenditures and Arms Transfers 2017. Washington, D.C. https://www.state.gov/t/avc/rls/rpt/wmeat/2017/index.htm

Wulf, H, ed. 1993. Arms Industry Limited. Oxford, UK: Oxford University Press.

Wulf, H. 2018 “Analysis of SIPRI's Arms Production Data: Some Suggestions for Expansion." The Economics of Peace and Security Journal. Vol. 13, No. 2, pp. 26-29. https://doi.org/10.15355/epsj.13.2.26

Yesilyurt, F., B. Güloglu, E. Yesilyurt, and S. Sezgin. 2014. "The Determinants of Arms Production." Defence and Peace Economics. Vol. 25, No. 2, pp. 205-211. https://doi.org/10.1080/10242694.2013.804670 
Appendix Table A1

Method 1. Illustrative estimates of major weapons production, selected countries, 2015 (2015 TIVs in millions)

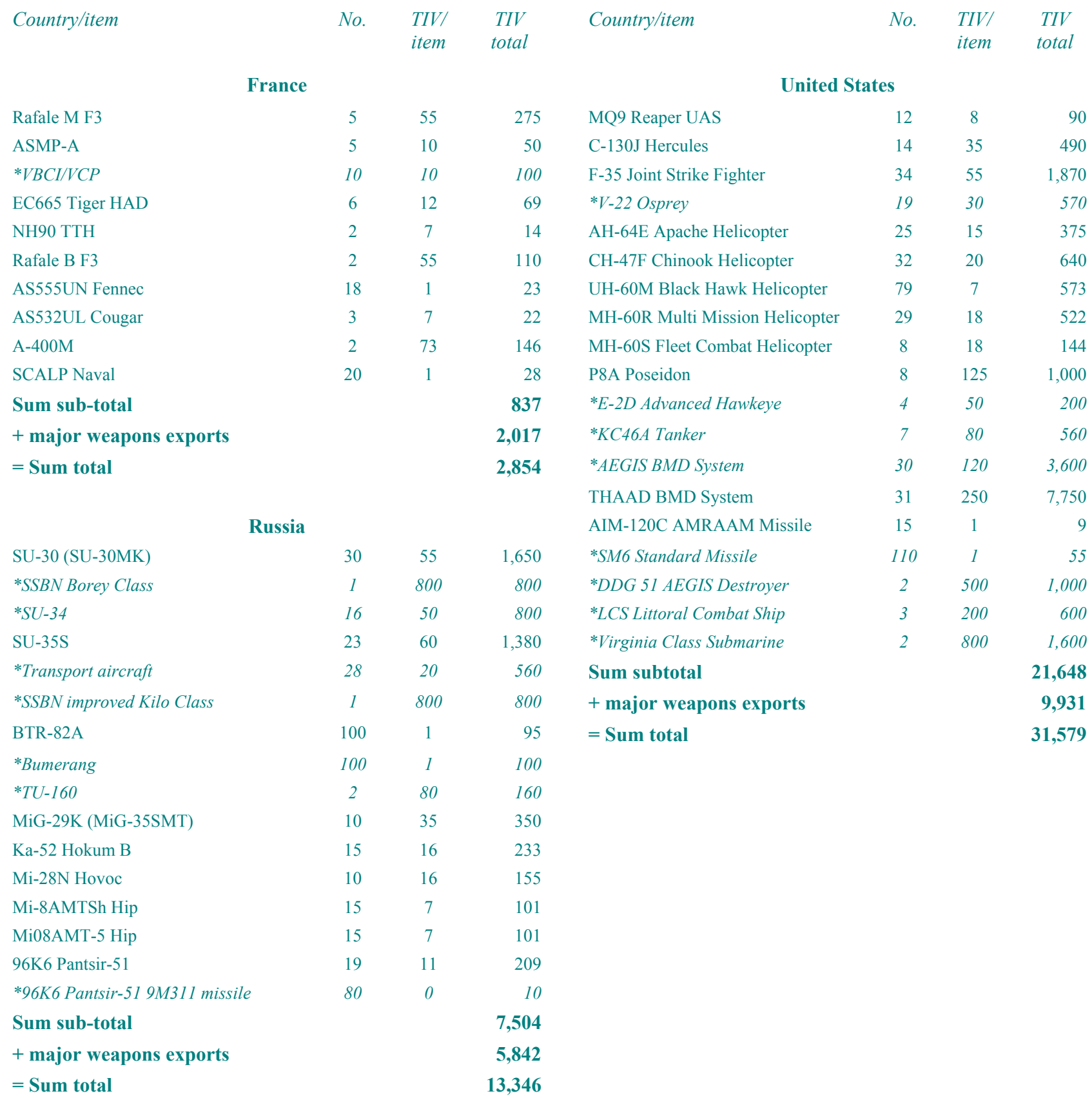

Note: The data on the number and type of nationally produced weapon systems accepted into service in 2015 is preliminary and is used here to present the principles of method 1 alone. Sources: Procurement: France: IISS; United States; U.S. Department of Defense; Russia: IISS Military Balance 2016. TIVs and major weapons exports: SIPRI (2019) and author's estimates (in italics). Items listed in italics and preceded by an asterisk (*) are the author's estimates, not SIPRI's. 
Appendix Table A2

Method 2. Illustrative estimates of arms production, selected countries, 2010-2015 (USD billions, in 2015 prices)

\begin{tabular}{|c|c|c|c|c|c|c|}
\hline & 2010 & 2011 & 2012 & 2013 & 2014 & 2015 \\
\hline \multicolumn{7}{|l|}{ France } \\
\hline Procurement & 15,692 & 14,207 & 15,508 & 12,437 & 12,345 & 12,423 \\
\hline Exports & 5,332 & 5,342 & 4,435 & 5,242 & 5,109 & 6,721 \\
\hline Imports & 1,600 & 1,700 & 1,800 & 1,400 & 1,100 & 1,100 \\
\hline Total & 19,429 & 17,849 & 18,144 & 16,279 & 16,354 & 18,044 \\
\hline \multicolumn{7}{|l|}{ GERMANY } \\
\hline Procurement & 8,138 & 7,448 & 7,679 & 5,578 & 5,590 & 5,221 \\
\hline Exports & 6,844 & 7,930 & 6,239 & 7,896 & 5,279 & 8,716 \\
\hline Imports & 3,700 & 3,800 & 4,000 & 3,000 & 2,400 & 2,100 \\
\hline Total & 11,282 & 11,578 & 9,918 & 10,474 & 8,469 & 11,837 \\
\hline \multicolumn{7}{|c|}{ UNITED KINGDOM } \\
\hline Procurement & 14,760 & 13,066 & 10,654 & 12,758 & 13,111 & 12,129 \\
\hline Exports & 4,084 & 10,258 & 3,534 & 7,068 & 3,434 & 8,893 \\
\hline Imports & 1,180 & 1,230 & 1,230 & 1,180 & 1,000 & 920 \\
\hline Total & 17,664 & 22,094 & 12,957 & 18,646 & 15,545 & 20,102 \\
\hline \multicolumn{7}{|c|}{ UNITED STATES } \\
\hline Procurement & 173,073 & 195,849 & 185,092 & 166,526 & 158,710 & 150,800 \\
\hline Exports & 56,865 & 66,852 & 52,836 & 41,918 & 82,686 & 95,393 \\
\hline Imports & 5,900 & 5,400 & 5,900 & 5,400 & 5,200 & 4,700 \\
\hline Total & 224,038 & 257,301 & 232,027 & 203,043 & 236,195 & 241,493 \\
\hline \multicolumn{7}{|l|}{ PR CHINA } \\
\hline Procurement & 37,903 & 40,126 & 43,523 & 44,585 & 49,178 & 51,521 \\
\hline Exports & 3,500 & 1,800 & 2,300 & 2,800 & 2,100 & 2,900 \\
\hline Imports & 1,200 & 700 & 1,100 & 1,000 & 1,300 & 500 \\
\hline Total & 40,203 & 41,226 & 44,723 & 46,385 & 49,978 & 53,921 \\
\hline \multicolumn{7}{|l|}{ RUSSIA } \\
\hline Procurement & 11,630 & 12,171 & 14,089 & 13,846 & 15,083 & 15,984 \\
\hline Exports & 10,870 & 14,436 & 15,691 & 15,974 & 15,618 & 14,500 \\
\hline Imports & 700 & 600 & 600 & 500 & 700 & 200 \\
\hline Total & 21,800 & 26,007 & 29,181 & 29,320 & 30,002 & 30,284 \\
\hline
\end{tabular}

Note: The data is rough, and preliminary estimates are for the purpose of presenting the principle of estimation only.

Sources: Procurement data: For NATO countries, estimated by multiplying defense spending with the relevant share of "equipment expenditures"; data taken from NATO (2017). For Russia and China, estimated by multiplying data from the SIPRI military expenditure data series with the average share of "equipment expenditures" for France, U.K., and U.S.; data taken from NATO (2017). Export data: Taken from SIPRI database on the financial value of the global arms trade, except for China, which is taken from U.S. Department of State (2017) (identical to the export values in Theohary, 2016). Where the SIPRI database offered different options, the following were chosen: France, arms exports; Germany, arms export licences; U.K., arms export licences; U.S., arms exports (FMS) + arms export licences (commercial sales). Import data: U.S. Department of State (2016), except for the U.K., which is the author's own estimate. 
Appendix Table A3

Method 3. Illustrative estimates of arms production, selected countries, 2010-2015 (USD billions, in 2015 prices)

$\begin{array}{lllll}2010 & 2011 & 2012 & 2013 & 2014\end{array}$

\section{FRANCE}

Method 2

SIPRI Top-100 sales

Average of methods 2 and 3

\section{GERMANY}

Method 2

SIPRI Top-100 sales

Average of methods 2 and 3

\section{UNITED KINGDOM}

Method 2

SIPRI Top-100 sales

Average of methods 2 and 3

\section{UNITED STATES}

Method 2

SIPRI Top-100 sales

Average of methods 2 and 3

\section{RUSSIA}

Method 2

SIPRI Top-100 sales

Average of methods 2 and 3

$\begin{array}{llllll}19,429 & 17,849 & 18,144 & 16,279 & 16,354 & 18,044 \\ 24,864 & 23,338 & 23,955 & 24,925 & 22,936 & 24,763 \\ 22,146 & 20,594 & 21,049 & 20,602 & 19,645 & 21,403\end{array}$

11,282

11,578

9,918

10,474

8,469

11,837

14,150

13,065

10,642

12,152

11,959

11,913

12,716

12,322

10,280

11,313

10,214

11,875

$\begin{array}{rrrrrr}17,664 & 22,094 & 12,957 & 18,646 & 15,545 & 20,102 \\ 31,091 & 31,775 & 31,447 & 31,897 & 29,253 & 26,477 \\ 24,377 & 26,934 & 22,202 & 25,271 & 22,399 & 23,289 \\ & & & & & \\ 224,038 & 257,301 & 232,027 & 203,043 & 236,195 & 241,493 \\ 291,151 & 269,765 & 248,498 & 236,295 & 225,958 & 214,778 \\ 257,594 & 263,533 & 240,263 & 219,669 & 231,077 & 228,135\end{array}$

$21,800 \quad 26,007$

29,181

29,320

30,002

30,284

11,856

13,089

16,634

20,923

24,223

25,093

16,828

19,548

22,907

25,122

27,122

27,688

Notes: The data for companies was aggregated by country, as given in the SIPRI database. Where subsidiaries are listed under a different country than their holding companies, corrections were made to the sales of holding companies. Sales of trans-European companies were divided between France (40\%), Germany (40\%) and the UK (10\%). Source for sales data: SIPRI arms industry database. 